\title{
Pengaruh Penerapan Strategi Pembelajaran REACT (Relating, Experiencing, Applying, Cooperating, dan Transferring) Terhadap Hasil Belajar Siswa Pada Materi Konsep Asam Basa
}

\author{
Alfath F. Taraufu ${ }^{* a}$, Dokri Gumolung, ${ }^{a}$ Joice D.S Caroles ${ }^{a}$
}

a Pendidikan Kimia, FMIPA, Universitas Negeri Manado, Minahasa, Tondano Selatan, 95618, Indonesia

\section{INFO ARTIKEL}

Diterima 21 Juli 2020

Disetujui 30 Desember 2020

\section{Keywords:}

REACT

Acid Bases

Attitudes

Learning Outcomes

Kata kunci:

REACT

Asam Basa

Sikap

Hasil Belajar
${ }^{*}$ e-mail:

taraufualfath@gmail.com

\section{A B STRACT}

This study aims to determine the effect of the application of REACT learning strategies on student learning outcomes on the concept of acid and base. This research was conducted at SMA Negeri 1 Tondano in the 2019/2020 school year in class XI IPA 1 with respondents totalling 23 students. Acid-base concept material applied in class XI IPA 1 is associated with everyday life. Data processing results in the relationship between questionnaire and posttest scores showed a positive response in learning using the REACT learning strategy. Research data in the form of questionnaire and posttest were analyzed through hypothesis testing, namely simple regression tests and product-moment correlation tests. Simple regression test shows that the higher the attitude of students towards the REACT learning strategy $(X)$, the higher the student learning outcomes $(Y)$, this shows the influence of variable $X$ (attitude) and variable $Y$ (learning outcomes). The product-moment correlation analysis results obtained by $r_{x y}$ value of 0.6466 , which indicates a strong relationship level. The determinant coefficient results determine the effect on REACT learning on learning outcomes obtained by $41.82 \%$. From the results received, there is an effect of the application of the REACT learning strategy to student learning outcomes on the concept of acid and base.

\section{A B S T R A K}

Penelitian ini bertujuan untuk mengetahui besarnya pengaruh penerapan strategi pembelajaran REACT terhadap hasil belajar siswa pada materi konsep asam basa. Penelitian ini dilaksanakan di SMA Negeri 1 Tondano pada tahun ajaran 2019/2020 di kelas XI IPA 1 dengan responden berjumlah 23 siswa. Materi konsep asam basa yang diterapkan di kelas XI IPA 1 dikaitkan dengan kehidupan sehari-hari. Hasil pengolahan data hubungan antara nilai angket dan posttest menunjukan respon positif dalam pembelajaran menggunakan strategi pembelajaran REACT. Data hasil penelitian berupa angket dan posttest dianalisis melalui uji hipotesis yaitu uji regresi sederhana dan uji korelasi product moment. Uji regresi sederhana menunjukan bahwa semakin tinggi sikap siswa terhadap strategi pembelajaran REACT (X) maka semakin tinggi hasil belajar siswa $(\mathrm{Y})$, hal ini menunjukan adanya pengaruh variabel $\mathrm{X}$ (sikap) dan variabel $\mathrm{Y}$ (hasil belajar). Hasil analisis korelasi product moment diperoleh nilai $\mathrm{r}_{\mathrm{xy}}$ yaitu 0,6466 yang menunjukan tingkat hubungan yang kuat. Hasil koefisien penentu untuk mengetahui pengaruh pada pembelajaran REACT terhadap hasil belajar diperoleh sebesar 41,82\%. Dari hasil yang diperoleh dapat dilihat bahwa adanya pengaruh penerapan strategi pembelajaran REACT terhadap hasil belajar siswa pada materi konsep asam basa. 


\section{Pendahuluan}

Salah satu dasar yang menentukan kemajuan suatu bangsa adalah pendidikan. Sebagai lembaga pendidikan formal sekolah dituntut agar dapat melaksanakan proses pembelajaran yang baik sehingga menghasilkan generasi muda yang cerdas, cekatan, kreatif, inovatif dan bermoral tinggi. Pada satuan pendidikan suatu proses pembelajaran diharuskan diselenggarakan secara intraktif, inspiratif, menyenangkan, menantang, memotivasi pembelajaran untuk meningkatkan efsiensi dan efektivitas kecapaian kompetensi kelulusan, tapi masih ada juga pembelajaran di sekolah yang menggunakan metode ceramah yang hanya berpusat pada guru yaitu bersifat satu arah saja sehingga berdampak pada tidak efektifnya hasil belajar siswa. Untuk memecahkan permasalahan tersebut perlu dilakukan model pembelajaran yang tidak hanya metode ceramah tapi dikombinasikan dengan model pembelajaran lain.

Pendekatan berbasis konteks (PBK) adalah salah satu pendekatan pembelajaran yang bisa meningkatkan hasil belajar siswa. Pendekatan Berbasis Konteks (PBK) didasarkan pada konstruktivisme dan memanfaatkan situasi di mana peserta didik menghubungkan pengetahuan yang dipelajari sebelumnya dengan pengetahuan yang baru diperoleh. Pendekatan berbasis konteks digunakan untuk memungkinkan peserta didik mengasosiasikan pengetahuan ilmiah mereka dengan peristiwa yang mungkin mereka temui dalam kehidupan setiap hari [1]. Sangat penting bahwa konteks yang digunakan untuk pendekatan berbasis konteks melibatkan topik dan aplikasi yang peserta didik dapat asosiasikan dengan budaya mereka sendiri, kehidupan sehari-hari, keluarga, dan teman-teman untuk mencapai pembelajaran yang efisien. Para siswa dapat bersama-sama meneliti, mendiskusikan dan mengembangkan solusi yang mungkin dalam kelompok kecil, sehingga meningkatkan pembelajaran mereka sendiri [2].

SMA Negeri 1 Tondano merupakan Sekolah Menengah Atas Negeri yang terletak di Provinsi Sulawesi Utara yang pada proses pembelajaran Kimia masih kurang menggunakan metode pembelajaran yang besifat dua arah sehingga siswa memiliki kesempatan yang terbatas untuk membuat hubungan antara pengetahuan ilmiah yang dipelajari di sekolah dengan dikehidupan sehari-hari dan mereka tidak memiliki banyak ide tentang mengapa mereka mempelajari semua mata pelajaran atau dimana menggunakannya. Berdasarkan observasi yang dilakukan, nilai KKM Pelajaran Kimia di SMA $\mathrm{N} 1$ Tondano adalah 75 dan data hasil belajar tahun ajaran 2019/2020 dari 181 siswa terdapat 63 siswa yang di atas KKM dan 118 siswa yang lainnya di bawah KKM. Salah satu materi kimia yang dapat dipelajari dan dikaitkan dengan kehidupan sehari-hari adalah Konsep Asam Basa. Pengajaran materi asam basa yang dihubungkan dengan kehidupan sehari-hari bermanfaat meningkatkan hasil belajar siswa dan memungkinkan siswa untuk mempertimbangkan topik dari berbagai sudut $[3,4]$.

Hasil penelitian yang dilakukan beberapa peneliti menunjukkan bahwa penggunaan pendekatan berbasis konteks (PBK) dengan strategi REACT lebih efektif daripada pengajaran secara kovensional [5]. Penerapan strategi REACT dapat meningkatkan pemahaman tentang materi kimia, telibat aktif dalam pembelajaran dan termotivasi untuk memecahkan permasalahan, serta dapat memahami materi dengan jelas [6,7]. Strategi REACT adalah salah satu penerapan strategi yang digunakan dalam pendekatan berbasis konteks (PBK) yang terdiri dari lima tahap: Relating, Experiencing, Applying, Cooperating dan Transferring. Penerapan strategi ini mendorong siswa untuk menghubungkan topik kimia dengan kehidupan sehari-hari sehingga meningkatkan wawasan dan hasil belajar siswa.

\section{Metode}

Pelaksanaan penelitian dilakukan di semester genap pada tahun ajaran 2019/2020 bulan Januari. Tempat dilakukannya penelitian yaitu di SMA Negeri 1 Tondano. Desain penelitian yang digunakan adalah One-Shot Case Study. 


\section{Hasil dan Pembahasan}

Pengujian Instrumen Penelitian

1. Uji Validitas

Instrumen berupa angket dan soal posttest yang telah dibuat diuji validitas pada kelas XII IPA 4 SMA Negeri 1 Tondano dimana sudah lebih dahulu mempelajari materi asam basa. Penentuan apakah valid atau tidaknya suatu instrumen dilakukan pengujian menggunakan bantuan Microsoft Excel 2010 dan rumus validitas yang digunakan untuk uji valid yaitu korelasi product moment. Taraf signifikansi yang digunakan yaitu 0,05 atau 5\% serta $n=20$ maka rabel yang digunakan adalah 0,444 . Pertanyaan angket yang disediakan peneliti sebanyak 15 nomor dan jumlah valid sebanyak 10 nomor. Soal posttest disediakan sebanyak 20 nomor dan yang valid adalah sebanyak 16 nomor.

\section{Uji Reliabilitas}

Uji reliabilitas angket dan soal posttest digunakan teknik belah dua (split half) dengan analisis menggunkana rumus Spearman Brown. Perolehan uji reliabilitas dari angket rhitung sebesar 0.8445 dan hasil uji reliabilitas soal posttest yaitu rhitung sebesar 0.9183 . Berdasarkan hasil yang didapatkan, maka angket dinyatakan reliabel sebab rhitung lebih besar dari rtabel $(0.8445>0,444)$ dan soal posttest dinyatakan reliabel sebab rhitung lebih besar dari rtabel $(0.9183>0,444)$, maka angket dan posttest layak digunakan sebagai instrumen penelitian.

\section{Pengujian Hipotesis}

1. Uji Regresi Sederhana

Uji regresi sederhana digunakan untuk mengetahui pengaruh variabel bebas $(X)$ dan variabel terikat $(Y)$. Hasil uji regresi sederhana dapat dilihat dalam diagram gambar 1 :

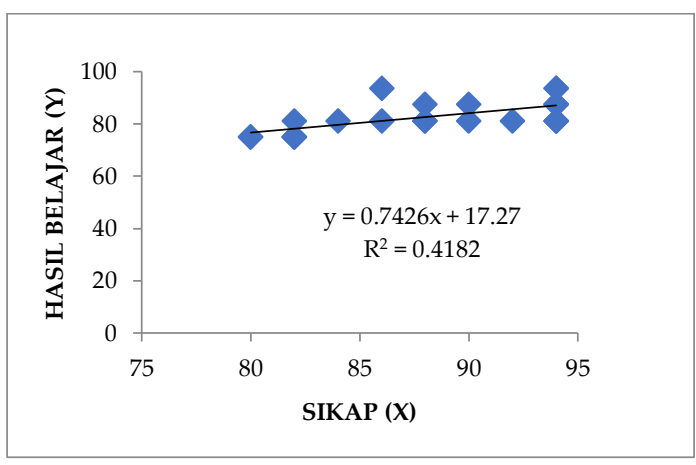

Gambar 1. Diagram Uji Regresi Sederhana
Diagram gambar 1 menunjukan bahwa terdapat pengaruh antara variabel $X$ (sikap) dan variabel $Y$ (hasil belajar). Persamaan regresi yang didapatkan yaitu $\mathrm{Y}=17,27+$ $0,7426 X$

\section{Uji Korelasi Product Moment}

Data yang diteliti apakah terdistribusi normal maka dilakukan perhitungan korelasi dengan rumus yang dipakai adalah korelasi Product Moment.

Tabel 1. Data Hasil Angket dan Soal Posttest

\begin{tabular}{|c|c|c|c|}
\hline \multicolumn{2}{|c|}{ Hasil Angket (X) } & \multicolumn{2}{|c|}{ Hasil Belajar (Y) } \\
\hline $\mathrm{N}$ & 23 & $\mathrm{~N}$ & 23 \\
\hline$X Y$ & 168862,50 & $x$ & 168862,50 \\
\hline$\sum X$ & 2032,00 & & 1906,25 \\
\hline$\sum X^{2}$ & 180128,00 & \rangle & 158789,06 \\
\hline \multicolumn{4}{|c|}{$r=0,64 \overline{66}$} \\
\hline \multicolumn{4}{|c|}{ Koefisien Penentu $(K P)=41,82 \%$} \\
\hline
\end{tabular}

Berdasarkan data pada tabel 1 maka terdapat korelasi antara sikap siswa terhadap penggunaan strategi pembelajaran REACT terhadap hasil belajar siswa pada materi asam basa dengan diperoleh $\mathrm{r}_{x y}$ sebesar 0,6466. Hasil tersebut menunjukan interval korelasi dengan tingkat hubungan yang kuat yaitu pada interval 0,60 - 0,79. Selanjutnya hasil koefisien penentu yang diperoleh yaitu $41,82 \%$, sehingga pengaruh strategi pembelajaran REACT terhadap hasil belajar siswa sebesar $41,82 \%$

\section{Pembahasan}

Penelitian ini dilakukan untuk mengetahui pengaruh penerapan strategi pembelajaran REACT terhadap hasil belajar siswa pada materi asam basa. Tempat dilaksanakannya penelitian yaitu SMA Negeri 1 Tondano di bulan Januari semester genap tahun ajaran 2019/2020 pada Kelas XI IPA 1 dengan jumlah responden sebanyak 23 siswa. Sebelum memulai penelitian, dilakukan konsultasi antara peneliti bersama dengan guru mata pelajaran di sekolah tersebut tentang kegiatan selama penelitian, baik uji validitas pada kelas XII IPA 4 dan Pembelajaran pada kelas XI IPA 1.

Selama tiga kali pertemuan pada materi 
konsep asam basa menggunakan strategi REACT, peneliti mengamati bahwa siswa merespon positif proses pembelajaran dengan giat saat melaksanakan pembelajaran baik saat memperhatikan guru selama mengajar maupun kerjasama dimasing-masing kelompok saat melaksanakan praktikum maupun diskusi. Pada tahap Relating, siswa menjadi aktif dalam menjawab saat diberikan bahasan yang berkaitan dengan kehidupan sehari-hari bahkan percaya diri bertanya pada pelajaran yang belum dimengerti. Selanjutnya pada tahap experiencing dan Applying baik diskusi maupun praktikum membangun pengetahuan siswa berperan aktif ketika melakukan praktikum untuk memecahkan permasalahan yang diberikan. Kegiatan pelaksanaan praktikum maupun diskusi ternyata dapat membimbing siswa untuk bekerjasama dalam pemecahan masalah. Perihal ini sejalan dengan penelitian sebelumnya yaitu pembelajaran REACT pada tahapannya yaitu siswa dibimbing untuk bekerjasama dalam memecahkan permasalahan sehingga membuat pengetahuan tersimpan dalam ingatan dan siswa lebih mengerti dengan konsepnya [8]. Pada tahapan Cooperating tercipta suasana diskusi yang aktif antar setiap kelompok yang memotivasi mereka untuk menjadi lebih baik dari kelompok lainnya sehingga menimbulkan ketertarikan siswa dalam belajar. Terakhir pada tahap Transfering, siswa menjadi berani bertanya pada kelompok lain saat belum memahami maksud dari hasil yang disampaikan. Kerjasama yang ditunjukan siswa ketika melaksanakan praktikum maupun diskusi menunjukan bahwa terjadinya interaksi sosial antara siswa. Perihal tersebut sama dengan penelitian sebelumnya yang menjelaskan bahwa dengan adanya pembelajaran diskusi dapat meningkatkan interaksi sosial antara siswa dalam membangun pengetahuan dan pemahaman mereka dan penelitian yang menunjukkan bahwa strategi pembelajaran REACT digunakan dalam pembelajaran agar siswa lebih aktif dalam proses pembelajaran [9-12]. Hasil yang diperoleh siswa juga dalam posttest berbentuk pilihan ganda sebanyak 16 nomor ini juga berada di atas KKM yaitu skor paling tinggi yaitu 93,75 dan yang terendah yaitu 75 . Siswa juga diberikan angket untuk melihat respon siswa dalam pembelajaran menggunakan strategi REACT. Angket yang dibagi menggunakan Skala Likert yaitu dengan 5 jawaban yaitu sangat setuju, setuju, ragu-ragu, tidak setuju, dan sangat tidak setuju yang masig-masing diberi poin 1-5. Hasil yang diperoleh yaitu skor tertinggi sebesar 94 dan yang terendah sebesar 80 . Data yang diperoleh menunjukan bahwa pembelajaran REACT berpengaruh positif terhadap respon siswa dan hasil belajar siswa. Perihal ini sejalan dengan penelitian yang menyatakan bahwa strategi pembelajaran REACT menciptakan suasana pembelajaran yang menyenangkan, lebih termotivasi untuk giat belajar dan mempermudah siswa dalam memecahkan permasalahan [13-15].

Setelah didapatkan data angket dan hasil belajar siswa, selanjutnya dilakukan analisis data dengan melakukan uji hipotesis. Uji hipotesis yang dipakai adalah uji regresi sederhana dan uji korelasi product moment. Uji regresi sederhana didapatkan persamaan regresi linier yaitu $\mathrm{Y}=17,27+0,7426 \mathrm{X}$. Diagram yang dijelaskan dalam sub.bab 4.3 menunjukan adanya pengaruh antara variabel $X$ dan variabel $Y$ yaitu semakin tinggi sikap siswa terhadap strategi pembelajaran REACT yaitu $X$ akan semakin tinggi hasil belajar siswa yaitu $Y$.

Hasil analisis korelasi product moment dihitung dengan berbantuan Microsoft Excel dengan memasukan hasil belajar siswa yaitu $\mathrm{Y}$ dan sikap siswa yaitu $X$ untuk menetukan nilai $\mathrm{r}$-hitung atau $\mathrm{r}_{\mathrm{xy}}$. Nilai $\mathrm{r}_{\mathrm{xy}}$ yang diperoleh yaitu 0,6466 yang menunjukan tingkat hubungan yang kuat yaitu pada interval korelasi 0,600,79 . Hasil koefisien penentu untuk mengetahui pengaruh penggunaan strategi pembelajaran REACT pada materi Konsep Asam Basa diperoleh 41,82\%, sedangkan sisanya $58,18 \%$ merupakan variabel di luar penelitian yang ikut berpengaruh dalam terbentuknya variabel dependen yaitu hasil belajar siswa. Respon positif pembelajaran REACT dapat dilihat dengan aktifitas pembelajaran siswa yang berperan aktif dalam proses pembelajaran baik diskusi maupun praktikum, berpengaruh terhadap hasil belajar 
dan mendapatkan respon siswa yang menyatakan setuju menggunakan strategi pembelajaran REACT karena menarik, dapat dihubungkan dengan kehidupan sehari-hari, meningkatkan kemauan belajar serta kerjasama antar siswa.

Hasil yang diperoleh menunjukan terdapat pengaruh dalam penerapan strategi pembelajaran REACT terhadap hasil belajar siswa pada materi Konsep Asam Basa yang dilaksanakan di SMA Negeri 1 Tondano.

\section{Kesimpulan}

Berdasarkan hasil dari penelitian yang dilakukan, peneliti menarik kesimpulan bahwa terdapat pengaruh dengan penerapan strategi pembelajaran REACT terhadap hasil belajar siswa pada SMA Negeri 1 Tondano dengan didapatkannya hasil koefisien korelasi sebesar $r_{x y}=0,6466$ dan koefisien penentu sebesar $41,82 \%$.

\section{Daftar Pustaka}

1. Ültay, E. Examination of Context- Based Problem-Solving Abilities of PRESERVICE PHYSICS Teachers. Journal of Baltic Science Education 2017, 16, 113-122.

2. Günter, T. The Effect of the REACT Strategy on Students' Achievements with Regard to Solubility Equilibrium: Using Chemistry in Contexts. Chemistry Education Research and Practice 2018, 19, 1287-1306, doi:10.1039/C8RP00087E.

3. Memah, R.A.; Gugule, S.; Gumolung, D. The Effect of Process Oriented Guided Inquiry Learning (POGIL) Model on Student Learning Outcomes in Acid Bases Titration Material in SMA Negeri 1 Kakas, Minahasa Regency. Oxygenius Journal Of Chemistry Education 2020, 2, 16-22.

4. Lumolos, G.; Gumolung, D.; Caroles, J. Studi Kelayakan Penuntun Praktikum Asam Basa Berbasis Bahan Lingkungan Menggunakan Model 3-D Dan Penerapan Metode Inkuiri Terbimbing Untuk Meningkatkan Hasil Belajar Siswa SMA Negeri 1 Tenga. Oxygenius Journal Of Chemistry Education 2019, 1, 40-47.

5. Taidi, Z.; Kapahang, A.; Mamuaja, M.N. Efektivitas Strategi REACT Terhadap Hasil
Belajar Siswa Pada Materi Larutan Penyangga Di Kelas XI SMA Negeri 2 Langowan. Oxygenius Journal Of Chemistry Education 2019, 1, 35-39.

6. Ismawati, R.; Saptorini, S.; Wijayati, N. Pengaruh Model Pembelajaran Inkuiri Berstrategi REACT Terhadap Hasil Belajar Kimia Siswa SMA Kelas XI. Jurnal Inovasi Pendidikan Kimia 2013, 7, 1044-1050.

7. Nisa, K.N.K.; Mahdian, M.; Hamid, A. Meningkatkan Keterampilan Proses Sains Dan Hasil Belajar Peserta Didik Dengan Model Pembelajaran React Pada Materi Sistem Koloid. JCAE (Journal of Chemistry And Education) 2019, 3, 40-46, doi:10.20527/jcae.v3i1.309.

8. Cahyono, B.A.D.; Sutarto, S.; Mahardika, I.K. Model Pembelajaran REACT (Relating,Experiencing,Applying,Cooperat ing, Transfering) Disertai Media Video Kejadian Fisika Terhadap Keterampilan Proses Sains Dan Hasil Belajar Siswa Dalam Pembelajaran Fisika Di SMA. Jurnal Edukasi 2017, 4, 20-24, doi:10.19184/jukasi.v4i3.6155.

9. Kupczynski, L.; Mundy, M.A.; Goswami, J.; Meling, V. Cooperative Learning in Distance Learning: A Mixed Methods Study. International Journal of Instruction 2012, 5, 81-90.

10. Fakhruriza, O.; Kartika, I. Keefektifan Model Pembelajaran Relating, Experiencing, Applying, Cooperating, Transferring (REACT) Untuk Meningkatkan Hasil Belajar Siswa SMP Pada Materi Kalor. Jurnal Riset dan Kajian Pendidikan Fisika 2015, 2, 54-57, doi:10.12928/jrkpf.v2i2.3250.

11. Cahyaningrum, R.; Febriana, B.W. Implementation of Relating, Experiencing, Applying, Cooperating, Transferring (REACT) Model to Students Learning Achievement in Chemical Basic Law Material at 10th Grade Students of SMA Negeri 1 Kalasan. International Journal of Chemistry Education Research 2019, 3, 35-42, doi:10.20885/ijcer.vol3.iss1.art6.

12. Harmin, A.A.; Darwis, Z.; Budi, S. Pengaruh Strategi React (Relating, Experiencing, Applying, Cooperating, Transfering) Terhadap Hasil Belajar 
Peserta Didik Pada Materi Asam Dan Basa. JRPK: Jurnal Riset Pendidikan Kimia 2020, 10, 34-38, doi:10.21009/JRPK.101.05.

13. Farid, A.; Nurhayati, S. Pengaruh Penerapan Strategi REACT Terhadap Hasil Belajar Kimia Siswa Kelas XI. Chemistry in Education 2014, 3, 36-42.

14. Nengsih, N.R.; Yusmaita, E.; Gazali, F. Evaluasi validitas konten dan konstruk bahan ajar asam basa berbasis REACT. EduKimia 2019, 1, 1-10, doi:10.24036/ekj.v1i1.104017.

15. Gazali, F.; Yusmaita, E. Analisis Prior Knowledge Konsep Asam Basa Siswa Kelas XI SMA Untuk Merancang Modul Kimia Berbasis REACT. Jurnal Eksakta Pendidikan 2018, 2, 202-208, doi:10.24036/jep/vol2-iss2/249.

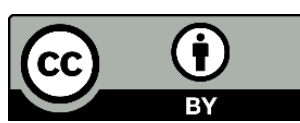

(C) 2020 by the authors. Licensee Oxygenius Journal Of Chemistry Education. This article is an open access article distributed under the terms and conditions of the Creative Commons Attribution (CC BY) license (http://creativecommons.org/licenses/by/4.0/). 